\title{
NILAI-NILAI PENDIDIKAN AKHLAK DALAM AL-QUR'AN SURAT AL-HUJURAT DAN LUQMAN: KAJIAN TAFSIR TARBAWI
}

\author{
Muhammad Ichwanuddin \\ IAIN Syekh Nurjati Cirebon \\ michwanuddin@gmail.com
}

DOI : 10.24235/oasis.v5i2.6081

Received

2020-02-17
Revised

2020-02-26
Approved

2021-03-21

\begin{abstract}
Moral values are the spirit of education. Moreover, moral dimension is the core of Muhammad's prophethood with al-Qur'an as his greatest miracle. This research is a qualitative study, included in the category of library research. Data collection is based on primary data and secondary data which is done by reading, studying, researching and collecting books that contain theories, opinions or the views of relevant experts. Data analysis was performed using descriptive-analytic techniques, reasoning methods, and comparative methods. This article concludes that Surah AlHujurat: 11-13 and Luqman verses 12-19 are full of moral education values. The difference between the two letters is Al-Hujurat: 11-13 instills moral values which lead to social transgression while Luqman 12-19 is more on individual transgression.
\end{abstract}

Keywords:Educational Values, Morals, Al-Qur'an

\begin{abstract}
Abstrak
Nilai-nilai pendidikan akhlak merupakan ruh dalam pendidikan.Dimensi akhlak yang merupakan inti dari kenabian Muhammad SAW dengan al-Qur'an sebagai mukjizat terbesarnya. Penelitian ini merupakan penelitian kualitatif, termasuk dalam kategori penelitian kepustakaan (library research). Pengumpulan data didasarkan pada data primer dan data skunder yang dilakukan dengan cara membaca, menelaah, meneliti dan mengumpulkan buku-buku yang berisi teori, pendapat atau pandangan para pakar yang terkait. Analisis data dilakukan dengan menggunakan teknik deskriptif-analitik, metode penalaran dan metode komparatif. Artikel ini menyimpulkan bahwa Surat Al-Hujurat: 1113 dan Luqman ayat 12-19 sarat dengan nilai-nilai pendidikan akhlak. Perbedaan kedua surat tersebut adalah Al-Hujurat: 11-13 menanamkan nilai akhlak yang menuju pada kesalihan sosial sedangkan Luqman 12-19 lebih pada kesalihan individu.
\end{abstract}

Kata Kunci:Nilai Pendidikan, Akhlak, Al-Qur'an

\section{Pendahuluan}

Al-Qur'an adalah mukjizat yang kekal dimana mukjizatnya selalu diperkuat oleh kemajuan ilmu pengetahuan. Ia diturunkan Allah kepada Rasulallah melalui Jibril untuk mengeluarkan manusia dari suasana yang gelap menuju yang terang, serta membimbing mereka ke jalan yang lurus(Al-Khattan, 1996: 1).

Al-Qur'an memuat begitu banyak aspek kehidupan manusia. Tidak ada rujukan yang lebih tinggi derajatnya dibandingkan dengan al-Qur'an yang hikmahnya meliputi seluruh alam dan 
isinya baik yang tersurat maupun yang tersirat tak akan pernah habis untuk digali dan dipelajari. Ketentuan-ketentuan hukum yang dinyatakan dalam al-Qur'an dan al-Hadist berlaku secara universal untuk semua waktu, tempat dan tak bisa berubah, karena memang tak ada yang mampu merubahnya.

Fenomena yang terjadi kehidupan umat manusia pada zaman sekarang ini sudah jauh dari nilai-nilai al-Qur'an. Padahal Al-Qur'an sebagai ajaran suci umat Islam, di dalamnya berisi petunjuk menuju ke arah kehidupan yang lebih baik, tinggal bagaimana manusia memanfaatkannya.Menanggalkan nilainilai yang ada di dalamnya berarti menanti datangnya masa kehancuran.Sebaliknya kembali kepada al-Qur'an berarti mendambakan ketenangan lahir dan bathin, karena ajaran yang terdapat dalam al-Qur'an berisi kedamaian. Ketika umat Islam menjauhi al-Qur'anatau sekedar menjadikan al-Qur'anhanya sebagai bacaan keagamaan maka sudahpasti alQur'an akan kehilangan relevansinya terhadap realitas-realitas alam semesta. Kenyataannya orang-orang di luar Islamlah yang giat mengkaji realitas alam semesta sehingga mereka dengan mudah dapat mengungguli bangsa-bangsa lain, padahal umat Islamlah yang seharusnya memegang semangat al- Qur'an(AlGhazali, 1999: 21).

Melalaikan al-Qur'an berakibat pada penyimpangan terhadap nilai kehidupan yang mudah ditemukan di lapisan masyarakat. Minimnya pengetahuan masyarakat terhadap pemahaman al-Qur'an, akan semakin memperparah kondisi masyarakat berupa dekadensi moral. Oleh karena itu, untuk memurnikan kembali kondisi yang sudah tidak relevan dengan ajaran Islam, satu- satunya upaya yang dapat dilakukan adalah dengan kembali kepada ajaran yang terdapat di dalamnya.

Sangat memprihatinkan bahwa kemerosotan akhlak tidak hanya terjadi pada kalangan muda, tetapi juga terhadap orang dewasa, bahkan orang tua. Kemerosotan akhlak pada anak-anak dapat dilihat dengan banyaknya siswa yang tawuran, mabuk, berjudi, durhaka kepada orang tua bahkan sampai membunuh sekalipun. Untuk itu, diperlukan upaya strategis untuk memulihkan kondisi tersebut, di antaranya dengan menanamkan kembali akan pentingnya peranan orang tua dan pendidik dalam membina moral anak didik.

Islam sebagai agama yang universal meliputi semua aspek kehidupan manusia mempunyai sistem nilai yang mengatur hal-hal yang baik, yang dinamakan dengan akhlak Islami.Sebagai tolak ukur perbuatan baik dan buruk mestilah merujuk kepada ketentuan Allah SWT dan Rasul-Nya, karena Rasulallah SAW adalah manusia yang paling mulia akhlaknya.

Pendidikan akhlak merupakan faktor yang sangat penting dalam membangun sebuah rumah tangga yang sakinah. Suatu keluarga yang tidak dibangun dengan tonggak akhlak mulia tidak akan dapat hidup bahagia sekalipun kekayaan materialnya melimpah ruah. Sebaliknya terkadang suatu keluarga yang serba kekurangan dalam masalah ekonominya, dapat bahagia berkat pembinaan akhlak keluarganya. Pendidikan akhlak di dalam keluarga dilaksanakan dengan contoh dan teladan dari orang tua dalam hubungan dan pergaulan antara ibu dan bapak (Daradjat, 1995: 60), perlakuan orang tua terhadap anak-anak mereka, dan perlakuan orang 
tua terhadap orang lain di dalam lingkungan keluarga dan lingkungan masyarakat, akan menjadi teladan bagi anak-anak (Baraja, 1999: 2).

Selain al-Qur'an, hadits Nabi dapat dijadikan rujukan mengingat salah satu fungsi hadits adalah menjelaskan kandungan ayat yang terdapat di dalamnya. Penulis melihat, bahwa surat al-Hujurat ayat 11-13 dan Luqman ayat 12-19 memiliki kandungan (makna) tentang pendidikan akhlak yang sangat dalam. Oleh karena itu, ayat tersebut sangat penting dan perlu digali lebih dalam untuk dijadikan rujukan dan pedoman bagi umat Muslim dalam rangka pembelajaran, pembentukan serta pembinaan akhlak yang mulia.

\section{Metode}

Penelitian ini merupakan library research yaitu penelitian yang obyek utamanya buku-buku kepustakaan dan literatur-literatur lainnya (Hadi, 2000: 9). Berdasarkan tujuannya penelitian ini termasuk basic research, yaitu penelitian dalam rangka memperluas dan memperdalam pengetahuan secara teoritis (Warsito, 1995: 9).

Dalam penelitian ini pengumpulan data didasarkan atas data primer dan data skunder. Data primer adalah data yang diperoleh langsung dari sumbernya, diamati dan dicatat untuk pertama kalinya. Selanjutnya, data skunder adalah data yang diusahakan sendiri pengumpulannya oleh peneliti (Marzuki, 2002: 55-56). Adapun data primer dalam penelitian ini adalah tafsir Al-Qur'an Al-'Azhim karya Ibnu Katsir, tafsir Al-Munir karya Wahbah Azzuhaili, tafsir Al-Maraghi juz karya Mushtafa Al-Maraghi, dan tafsir AL-Azhar karya Hamka, dan tafsir Al-
Mishbah karya Muhammad Quraish Shihab. Adapun data skundernya adalah pelbagai buku tentang nilai-nilai pendidikan Islam, buku-buku tentang kepribadian anak serta buku-buku yang menunjang kevalidan data yang sifatnya sebagai pelengkap.

Adapun teknis analisa data yang digunakan dalam pembahasan ini adalah:

\section{a. Deskriptif-analitik}

Metode ini berupaya memecahkan atau menjawab permasalahan yang sedang dihadapi pada masa sekarang. Dilakukan dengan menempuh langkah-langkah pengumpulan, klasifikasi, analisa atau membuat kesimpulan laporan secara menyeluruh dan sistematis(Margono, 1997: 37).

\section{b. Metode Penalaran}

Metode penalaran yang digunakan dalam pembahasan ini adalah:

1) Teknik induktif.

Digunakan untuk menyelesaikan masalah dan fakta yang bersifat khusus, lalu peristiwa-peristiwa itu digeneralisasikan (Hadi, 2000: 9). Teknik ini digunakan pada pengumpulan datadata tentang pendidikan Islam, kepribadian dan ruang lingkupnya yang masih berserakan sehingga membentuk sebuah sistem.

2) Teknik deduktif.

Digunakan untuk menganalisa masalah-masalah yang bersifat umum menuju kepada yang khusus. Teknik ini dipakai dalam pembahasan tentang nilainilai pendidikan yang ada dalam surat Luqman.

3) Teknik komparatif. 
Digunakan untuk membandingkan analisa teks dengan pendapat-pendapat para pakar pendidikan melalui buku-buku karya mereka. Teknik ini terutama digunakan untuk menganalisa persepsi nilai-nilai pendidikan dalam surat alHujurat: 11-13 dan Luqman ayat 12-19 dalam hubungan individual dan sosial.

\section{Hasil dan bahasan}

\section{Pendidikan Akhlak dalam Perspektif}

Pendidikan akhlak adalah pendidikan yang berusaha mengenalkan, menanamkan serta menghayatkan anak akan adanya sistem nilai yang mengatur pola, sikap dan tindakan manusia atas isi bumi. Pola sikap dan tindakan yang dimaksud mencakup pola-pola hubungan dengan Allah, sesama manusia (termasuk dengan dirinya sendiri) dan dengan alam sekitar (Ishak, 1993: 205). Dari penjelesan di atas dapat dikatakan bahwa pendidikan akhlak adalah suatu pendidikan yang berusaha mengimplementasikan nilai keimanan seseorang dalam bentuk perilaku (Darajat, 1991: 58). Sebab pendidikan akhlak adalah bagian yang tidak dapat dipisahkan dari pendidikan agama. Sehingga sesuatu, dianggap baik atau buruk oleh seseorang manakala berdasar pada agama (Langgulung, 1991: 373).

Ibrahim Amini (2006: 5) dalam bukunya Agar Tak Salah Mendidik mengatakan bahwa pendidikan adalah memilih tindakan dan perkataan yangsesuai, menciptakan syarat-syarat dan faktorfaktor yang diperlukan dan membantu seorang individu yang menjadi objek pendidikan supaya dapat dengan sempurna mengembangkan segenap potensi yang ada dalam dirinya dan secara perlahan-lahan bergerak maju menuju tujuan dan kesempurnaan yang diharapkan.
Ramayulis (2002: 3) mengutip pendapat Athiyah al-Abrasyi mengatakan, pendidikan ialah adalah mempersiapkan manusia supaya hidup dengan sempurna dan bahagia, mencintai tanah air, tegap jasmaninya, sempurna budi pekertinya (akhlaknya), teratur pikirannya, halus perasaannya, mahir dalam pekerjaannya, manis tutur katanya baik dengan lisan atau tulisan.

Dalam pengertian yang agak luas, pendidikan dapat diartikan sebagai sebuah proses dengan metode-metode tertentu sehingga orang memperoleh pengetahuan, pemahaman, dan cara bertingkah laku yang sesuai dengan kebutuhan. Pendapat lain mengatakan bahwa pendidikan berarti tahapan kegiatan yang bersifat kelembagaan (seperti sekolah dan madrasah) yang digunakan untuk menyempurnakan perkembangan individu dalam menguasai pengetahuan, kebiasaan, sikap dan sebagainya. Pendidikan dapat berlangsung secara informal dan nonformal di samping secara formal seperti di sekolah, madrasah, dan institusi-institusi lainnya (Syah, 2004: 11).

Dengan demikian pendidikan berarti, segala usaha orang dewasa baik sadar dalam pergaulan dengan anak-anak untuk memimpin perkembangan jasmani dan rohaninya ke arah kedewasaan menuju terciptanya kehidupan yang lebih baik.

Istilah tarbiyah menurut para pendukungnya berakar pada tiga kata. Pertama, kata rabayarbu yang berarti bertambah dan tumbuh. Kedua, kata rabiya yarba berarti tumbuh dan berkembang. Ketiga, rabba yarubbu yang berarti memperbaiki, menguasai, memimpin, menjaga dan memelihara. Kata $a l-R a b b$, juga berasal dari kata tarbiyah dan berarti mengantarkan sesuatu kepada kesempurnaannya secara bertahap atau 
membuat sesuatu menjadi sempurna secara berangsur- angsur (Aly, 1999: 4).

Firman Allah yang mendukung penggunaan istilah ini adalah: Dan rendahkanlah dirimu terhadap mereka berdua dengan penuh kesayangan dan ucapkanlah: "Wahai Tuhanku, kasihilah mereka keduanya, sebagaimana mereka berdua telah mendidik aku waktu kecil. (QS al-Isra [17]: 24)

Istilah lain yang digunakan untuk menunjuk konsep pendidikan dalam Islam ialah ta"lim. Ta"lim adalah proses pembelajaran secara terus menerus sejak manusia lahir melalui pengembangan fungsi-fungsi pendengaran, penglihatan dan hati. Proses ta "lim tidak berhenti pada pencapaian pengetahuan dalam wilayah kognisi semata, tetapi terus menjangkau wilayah psikomotor dan afeksi.

Sedangkan kata ta'dib seperti yang ditawarkan ialah pengenalan dan pengakuan tentang hakikat bahwa pengetahuan dan wujud bersifat teratur secara hirarkis sesuai dengan berbagai tingkatan dan derajat tingkatannya serta tentang tempat seseorang yang tepat dalam hubungannya dengan hakikat itu serta dengan kapasitas dan potensi jasmani, intelektual, maupun rohani seseorang. Dengan pengertian ini mencakup pengertian ilm dan amal (Aly, 1999: 9).

Selanjutnya definisi akhlak. Kata Akhlak berasal dari bahasa Arab, jamak dari khuluqun yang menurut bahasa berarti budi pekerti, perangai, tingkah laku dan tabiat (Mustafa, 1999: 11). Tabiat atau watak dilahirkan karena hasil perbuatan yang diulang- ulang sehingga menjadi biasa. Perkataan ahklak sering disebut kesusilaan, sopan santun dalam bahasa Indonesia; moral, ethnic dalam bahasa Inggris, dan ethos, ethios dalam bahasa Yunani.Kata tersebut mengandung segi- segi persesuaian dengan perkataan khalqun yang berarti kejadian, yang juga erat hubungannya dengan khaliq yang berarti pencipta; demikian pula dengan makhluqun yang berarti yang diciptakan. Definisi akhlak menurut istilah ialah kehendak jiwa manusia yang menimbulkan perbuatan dengan mudah karena kebiasaan, tanpa memerlukan pertimbangan pikiran terlebih dahulu.

Abuddin Nata (2005: 274) berpendapat bahwa ada lima ciri yang terdapat dalam perbuatan akhlak. Pertama perbuatan akhlak tersebut sudah menjadi kepribadian yang tertanam kuat dalam jiwa seseorang. Kedua perbuatan akhlak merupakan perbuatan yang dilakukan dengan acceptable dan tanpa pemikiran (unthouhgt).Ketiga, perbuatan akhlak merupakan perbuatan tanpa paksaan. Keempat, perbuatan dilakukan dengan sebenarnya tanpa ada unsur sandiwara. Kelima, perbuatan dilakukan untuk menegakkan kalimat Allah.

Dengan demikian dari definisi pendidikan dan akhlak di atas dapat disimpulkan bahwa pendidikan akhlak adalah usaha sadar dan tidak sadar yang dilakukan oleh seorang pendidik untuk membentuk tabiat yang baik pada seorang anak didik, sehingga terbentuk manusia yang taat kepada Allah. Pembentukan tabiat ini dilakukan oleh pendidik secara kontinue dengan tidak ada paksaan dari pihak manapun.

\section{Nilai Pendidikan Akhlak Surat Al- Hujurat Ayat 11-13}

Surat yang tidak lebih dari 18 ayat ini termasuk surat Madaniah. Surat ini merupakan surah yang agung dan besar dan mengandung aneka hakikat akidah serta syariah yang penting; mengandung 
hakikat wujud dan kemanusiaan. Hakikat ini merupakan cakrawala yang luas dan jangkauan yang jauh bagi akal dan kalbu. Surat ini juga menimbulkan pikiran yang dalam dan konsep yang penting bagi jiwa dan nalar. Hakikat itu meliputi berbagai manhaj (cara) penciptaan, penataan, kaidah-kaidah pendidikan dan pembinaan. Padahal jumlah ayatnya kurang dari ratusan (Qutbh, 2004: X/407) .

Surat al-Hujurat berisi petunjuk tentang apa yang harus dilakukan oleh seorang mukmin terhadap Allah SWT, terhadap Nabi dan orang yang menentang ajaran Allah dan Rasul-Nya, yaitu orang fasik. Pada pembahasan ini dijelaskan apa yang harus dilakukan seorang mukmin terhadap sesamanya dan manusia secara keseluruhan, demi terciptanya sebuah perdamaian. Adapun etika yang diusung untuk menciptakan sebuah perdamaian dan menghindari pertikaian yaitu menjauhi sikap mengolok-olok, mengejek diri sendiri, saling memberi panggilan yang buruk, suudhdhan, tajassus, ghibah, serta tidak boleh bersikap sombong dan saling membanggakan diri karena derajat manusia di hadapan Allah SWT sama. Berikut ini adalah bunyi lengkap surat alHujurat ayat 11-13:

Hai orang-orang yang beriman, janganlah suatu kaum mengolok-olok kaum yang lain, boleh jadi mereka (diperolok-olokkan) lebih baik dari mereka (yang mengolok-olok); dan jangan pula wanita-wanita (mengolokolokkan) terhadap wanita-wanita lain, boleh jadi mereka (yang diperolokolokkan) lebih baik dari mereka (mengolok-olokkan); dan janganlah kamu mengejek dirimu sendiri, dan janganlah kamu panggil memanggil dengan gelargelar buruk. Seburuk-buruk panggilan adalah kefasikan sesudah iman dan barangsiapa yang tidak bertaubat, Maka mereka itulah orang-orang yang zalim. Hai orang-orang yang beriman, jauhilah kebanyakan buruk sangka (kecurigaan), Karena sebagian dari buruk sangka itu dosa.dan janganlah mencari-cari keburukan orang dan janganlah menggunjing satu sama lain. Adakah seorang diantara kamu yang suka memakan daging saudaranya yang sudah mati?Maka tentulah kamu merasa jijik kepadanya dan bertakwalah kepada Allah. Sesungguhnya Allah Maha Penerima Taubat lagi Maha Penyayang. Hai manusia, Sesungguhnya kami menciptakan kamu dari seorang lakilaki dan seorang perempuan dan menjadikan kamu berbangsa-bangsa dan bersuku-suku supaya kamu saling kenalmengenal. Sesungguhnya orang yang paling mulia di antara kamu disisi Allah ialah orang yang paling takwa diantara kamu. Sesungguhnya Allah Maha mengetahui lagi Maha Mengenal.(13) (QSal-Hujurat [49]: 11-13)

Surat al-Hujurat ayat 11-13 memiliki makna yang luas dan mendalam, membahas tentang akhlak sesama kaum Muslim khususnya. Ayat ini dapat dijadikan pedoman agar terciptanya sebuah kehidupan yang harmonis, tentram dan damai.Sebagai makhluk sosial setiap manusia tentu tidak ingin haknya tergganggu. Oleh karena itu, di sinilah pentingnya bagaimana memahami agar hak (kehormatan diri) setiap orang tidak tergganggu sehingga tercipta kehidupan masyarakat harmonis.

Surat al- Hujurat ini merupakan di antara sekian banyak surat yang membicarakan nilai-nilai pendidikan akhlak. Berikut ini adalah uraian lebih jelasnya: 


\section{Menjunjung Kehormatan Kaum Muslimin}

Dalam ayat 11 tersebut Allah SWT tidak hanya memerintahkan untuk menjunjung kehormatan/nama baik kaum Muslimin. Akan tetapi, dijelaskan pula cara menjaga nama baik/menjunjung kehormatan kaum Muslimin tersebut.

Seorang Muslim mempunyai hak atas saudaranya sesama Muslim, bahkan dia mempunyai hak yang bermacammacam. Hal tersebut telah banyak dijelaskan oleh Nabi Muhammad SAW dalam banyak tempat bahwa orang Muslim terhadap muslim lainnya adalah bersaudara dan bagaikan satu tubuh yang bila salah satu anggotanya mengaduh sakit maka sekujur tubuhnya akan merasakan demam dan tidak bisa tidur (Rifai, 2000: IV/429). Oleh karena itu, sangatlah rasional apabila sesama Muslim harus menjaga kehormatan orang lain dan saling menolong (dalam hal kebaikan) apabila ada saudaranya yang membutuhkan bantuan.

Seseorang yang mengolok-olok saudaranya, menghina, dan memberikan panggilan yang buruk berarti ia telah merendahkan orang tersebut dan sekaligus tidak menjunjung kehormatan kaum Muslimin (Al-Maraghi, 1992: 26/213). Sebaliknya, menjunjung kehormatan kaum Muslimin merupakan kewajiban setiap umat. Hal ini sebagaimana yang dijelaskan dalam sebuah sabda Nabi Muhammad SAW yang diriwayatkan Tirmidzi.

Dari Abu Hurairah Radhiyallahu Anhu, ia berkata, Rasulallah SAW bersabda, Sesama Muslim adalah bersaudara. Sesama Muslim tidak boleh menghianati, mendustai, dan menghinakannya. Sesama Muslim haram mengganggu kehormatan, harta, dan darahnya. Takwa itu ada di sini (sambil menunjuk dadanya). Seseorang cukup dianggap jahat apabila ia menghina saudaranya yang Muslim (Aziz, 1999: 449).

Dari hadist di atas dapat dipahami bahwa mengolok-olok orang lain adalah haram hukumnya dan siapa saja yang melakukannya maka ia akan mendapat dosa yang setimpal atas kesalahannya tersebut (Al-Maraghi, 1992: 26/214). Sikap mengolok-olok timbul karena adanya anggapan bahwa dirinya merasa lebih baik dari pada orang lain dan menilai seseorang hanya berdasarkan lahirnya saja. Padahal, ada kemungkinan seseorang yang tampak mengerjakan amal kebaikan, sementara di dalam hatinya nampak sifat yang tercela dan sebaliknya ada kemungkinan seseorang yang kelihatan melakukan yang perbuatan yang buruk padahal Allah SWT melihat dalam hatinya ada penyesalan yang besar serta mendorong dirinya untuk segera bertaubat atas dosa yang pernah dilakukannya. Maka dari itu, amal yang nampak dari luar hanyalah merupakan tanda-tanda saja yang menimbulkan sangkaan yang kuat, tetapi belum sampai kepada tingkat meyakinkan.

Islam telah menjaga kehormatan setiap orang dari perkataan yang tidak disukainya dan disebutkan, baik orang itu hadir atau ketika dia tidak ada, meskipun pernyataan itu sesuai kenyataan (Salminawati, 2016: 178). Maka bagaimana lagi jika perkataan itu mengada-ngada dan tidak ada dasarnya?Dengan demikian, perkataan itu merupakan kesalahan besar dan dosa besar.

Jenis pelanggaran yang paling berat terhadap kehormatan ialah menuduh perempuan-perempuan mukminah yang senantiasa menjaga kehormatannya dengan tuduhan melakukan perbuatan 
keji. Efek dari tuduhan tersebut akan membawa bahaya besar kalau mereka mendengarnya dan didengar pula oleh keluarganya dan juga akan membahayakan masa depan perempuan tersebut. Lebih-lebih jika hal itu didengar oleh orang-orang yang suka menyebarluaskan kejahatan di tengahtengah kaum mukminin (Qardawi, 2004: 400).

Sebuah hadits yang diriwayatkan Imam Muslim mengatakan, Dari Hammam bin harits, ia berkata, kami sedang duduk bersama Khudzaifah di masjid, kemudian datang seseorang lalu duduk di samping kami, dikatakan kepada Khudzaifah, "hal ini disampaikan kepada raja”, Khudzaifah berkata, akau ingin mendengar Rasulallah SAW, Rasulallah SAW bersabda, Tidak masuk surga tukang adu domba atau penyebar fitnah (An-Naisabury, 1996: 157).

Ghibah adalah menyebut seorang Muslim dengan sesuatu yang ada padanya dan itu tidak disukainya, baik cacat di badannya, agama, dunia, akhlak dan sifat kejadiannya. Bentuk ghibah bermacammacam antara lain, dengan menyebut aibnya, atau meniru tingkah lakunya dengan maksud mengejek.

Seseorang yang hadir di tempat yang sedang melakukan ghibah wajib mengingkari kemungkaran itu dan membela saudaranya yang dipergunjingkan, Islam telah menjaga kehormatan setiap orang dari perkataan yang tidak disukainya dan disebutkan ketika dia tidak ada, meskipun perkataan itu sesuai kenyataan. Dengan demikian perbuatan ini merupakan kesalahan dan dosa besar.

Langkah strategis yang dapat dilakukan seseorang untuk menjunjung kehormatan kaum Muslimin adalah dengan cara tidak mengolok-olok, tidak mencela dirinya sendiri, dan tidak memberikan panggilan yang tidak disenanginya.

\section{Taubat}

Imam Syafi'i menegaskan bahwa ilmu cahaya Allah ta'ala yang tidak akan diberikan kepada mereka yang masih melakukan kemaksiatan. Oleh karenanya, seorang penuntut ilmu harus bersih dari dosa-dosa dan untuk bersih dari dosa, taubat adalah jalannya (Thabrani, 2006: 208).

Taubat adalah awal atau permulaan di dalam hidup seseorang yang telah memantapkan diri untuk berjalan di jalan Allah (suluk). Taubat merupakan akar, modal atau pokok pangkal bagi orangorang yang berhasil meraih kemenangan. Seseorang yang telah berbuat dosa atau kesalahan sudah menjadi kewajiban baginya agar segera kembali (taubat) kepada Allah SWT, sehingga ia tidak bergelimang secara terus menerus dalam jurang kemaksiatan, yang akan membuatnya semakin jauh dari rahmat Allah SWT. Dengan kembali kepada Allah SWT diharapkan ia menjadi orang yang semakin dekat dengan sang khaliq.

Taubat haruslah dilakukan baik ketika seseorang berbuat dosa besar maupun kecil. Sebuah dosa kecil yang dilakukan secara terus menerus dan tidak segera diimbangi dengan taubat kepada Allah SWT, maka dosa atau kesalahan tersebut akan menumpuk menjadi dosa yang besar.

Taubat itu merupakan kata yang mudah untuk diucapkan, namun sulit untuk direalisasikan.Untuk mengetahui apakah seseorang itu telah benar-benar bertaubat atau belum, dapat dilihat dari ucapan, sikap dan tingkah laku orang 
tersebut setelah dirinya menyatakan bertaubat. Jika ia benar-benar bertaubat maka harus ada perubahan dalam hal-hal tersebut menuju ke arah yang lebih baik. Hal ini sesuai dengan firman Allah SWT yang berbunyi:

Sesungguhnya taubat di sisi Allah hanyalah taubat bagi orang-orang yang mengerjakan kejahatan lantaran kejahilan, yang kemudian mereka bertaubat dengan segera, maka mereka itulah yang diterima taubatnya; dan Allah Maha Mengetahui lagi Maha Bijaksana (QS an-Nisa [4]: 17).

Para ulama mengemukakan ada beberapa persyaratan bagi diterimanya taubat (An-Nawawi, 2000: 346):

a. Adanya penyesalan karena telah melakukan dosa. Bahkan, Rasulallah sendiri menganggap penyesalan adalah sebagai bentuk dari taubat itu sendiri, seperti dalam sabdanya; penyesalan adalah taubat

b. Melakukan langkah kongkrit untuk melepaskan diri dari perbuatan dosa, seperti menghindari dari segala sesuatu yang dapat menyeretnya kembali kepada perbuatan dosa.

c. Memiliki keinginan kuat untuk tidak mengulangi perbuatan dosa pada kesempatan yang lain. Orang yang benar-benar bertaubat tidak mungkin melakukan kesalahan yang sama.

d. Mengembalikan hak-hak orang lain yang pernah dirampasnya, sebagai bentuk pertaubatan. Jika hak orang lain yang pernah dirampasnya masih ada dan memungkinkan untuk dikembalikan maka ia harus mengembalikannya. Namun jika tidak, maka ia harus meminta kerelaannya.

e. Adanya perubahan nyata dalam ucapan dan perbuatan seseorang yang menyatakan bertaubat. Misalnya, terjadinya perubahan dari yang tercela menuju yang terpuji.

Untuk mengetahui apakah taubat seseorang diterima atau tidak dapat dilihat pada hal-hal berikut ini:

a. Seorang hamba lebih baik dari pada sebelumnya.

b. Hamba yang bertaubat terus diselimuti rasa takut terhadap dosanya dan tidak pernah merasa aman dari siksa Allah sekejap matapun.

c. Terbebasnya hati dari ikatan dosa tersebut, karena penyesalan dan rasa takutnya.

d. Di antara tuntutan taubat yang benar adalah adanya kelembutan hati yang khusus, yang tidak serupa dengan kelembutan yang manapun, kelembutan hati orang yang bertaubat dengan kelembutan yang sempurna, meliputi segala sisinya, sehingga menyebabkan dirinya tertunduk di hadapan Allah dalam kedaan pasrah dan penuh kekhusyuan.

Orang-orang yang melakukan taubat dengan sungguh-sungguh, kemudian Allah SWT menerima taubatnya maka orang tersebut diibaratkan seperti orang yang tidak berdosa.

\section{Berprasangka Baik}

Berburuk sangka merupakan akhlak tercela dan pelakunya akan mendapat dosa, oleh karenanya harus ditinggalkan. Islam mengajarkan kepada umatnya untuk berfikir positif khususnya bagi orang yang berkpribadian mulia. Dengan demikian husnudhdhan (positif thinking) haruslah dibiasakan agar kita menjadi pribadi yang unggul. Rasulullah SAW dalam sebuah sabdanya menegaskan bahwa umat Muslim harus menjauhi sifat buruk sangka yang tidak memiliki dasar yang bisa 
dipertanggungjawabkan (Asy-Syafi'i, 1993: 478).

Abu Hurairah r.a. berkata, Rasulallah SAW. bersabda, berhati-hatilah kalian dari buruk sangka sebab buruk sangka itu sedusta-dusta cerita (berita; Janganlah menyelidiki; jangan mematamatai (mengamati) hal orang lain, jangan hasut-menghasut; jangan benci-membenci, dan saling membelakangi. Jadilah kalian ini sebagai hamba Allah itu saudara. (HR Bukhari)

Buruk sangka adalah menyangka seseorang berbuat kejelekan atau menganggap jelek tanpa adanya sebabsebab yang jelas yang memperkuat sangkaannya.Buruk sangka seperti dinyatakan dalam hadits di atas sebagai sedusta-dustanya perkataan. Orang yang telah berburuk sangka terhadap orang lain berarti telah menganggap jelek kepadanya padahal ia tidak memiliki dasar sama sekali. Buruk sangka akan mengganggu hubungannya dengan orang yang dituduh jelek, padahal orang tersebut belum tentu sejelek persangkaannya.

Al-Maraghi mengutip sebuah riwayat Umar bin Khattab tentang larangan berprasangka buruk terhadap sesama muslim, janganlah sekali-kali kalian menyangka sesuatu perkataan yang keluar dari mulut saudara kalian yang beriman, kecuali sebagai sesuatu yang baik, karena kalian mendapatkan tempat yang baik untuk kata-kata itu. Uraian di atas menegaskan bahwa umat muslim dilarang berprasangka buruk terhadap ucapan sesama muslim, sebab dengan berprasangka baik maka kita akan memperoleh tempat yang baik pula(AlMaraghi, 1992: 21/89).

Buruk sangka dalam masalah akidah adalah haram hukumnya.Oleh karena itu, tidak benar jika keimanan kepada Allah
SWT hanya berdasarkan dugaan semata. Jika dicermati salah satu penyebab orangorang terdahulu tersesat adalah karena mereka tidak yakin dengan keimanan kepada Allah SWT.

\section{Saling Mengenal}

Pendidikan ta'aruf ini terdapat dalam firman Allah yang artinya: Maha suci Dzat yang telah menciptakan manusia berbangsa-bangsa dan bersukusuku, padahal pada awalnya manusia berasal dari sumber yang sama yaitu Adam dan Hawa.

Dengan kekuasaan dan kehendaknya terlahir manusia yang berbeda ras dan warna kulit dan sudah menjadi sunah-Nya bahwa segala yang diciptakannya tidak sia-sia. Perbedaan semua itu adalah agar semua manusia satu sama lain melakukan ta'aruf atau saling mengenal. Pada dasarnya manusia tidak bisa hidup tanpa bermasyarakat dan bantuan orang lain. Dengan ta'aruf rasa saling menyayangi akan timbul di antara sesama.

Ayat tersebut di atas menegaskan bahwa diciptakannya manusia berbangsabangsa, bersuku-suku adalah untuk saling mengenal, bekerja sama (dalam kebaikan) sekaligus menafikan sifat kesombongan dan berbangga-bangga yang disebabkan oleh bedanya nasab (keturunan). Ayat ini juga dapat dipahami bahwa diciptakannya manusia untuk mengenal Tuhannya.

Untuk menciptakan masyarakat yang harmonis tidak cukup hanya dengan ta"aruf (saling mengenal), akan tetapi harus dibina dan dipupuk dengan subur melalui upaya yang dapat membuat hubungan di antara manusia dapat bertahan lama. Upaya ini dikenal dengan istilah silaturrahim. Silaturrahim artinya menyambungkan tali persaudaraan. Silaturrahim merupakan ajaran yang harus 
senantiasa dipupuk agar bisa tumbuh dengan subur. Selain itu, silaturrahim memiliki nilai yang luas dan mendalam, yang tidak hanya sekedar menyambungkan tali persaudaraan, lebih daripada itu, silaturrahim juga bisa dijadikan sebagai sarana untuk mempermudah datangnya sebuah rezeki (Asy-Syafi'i, 1993: 478). Hal ini sesuai dengan sabda Nabi yang berbunyi: Siapa yang ingin diluaskan rezekinya dan dilanjutkan umurnya, hendaklah ia menyambung hubungan famili (kerabat) (HR Bukhari).

Hadits di atas kalau dicermati dengan seksama sangatlah logis, orang yang selalu bersilaturrahim tentunya akan memiliki banyak teman relasi dan relasi merupakan salah satu faktor yang akan menunjang kesuksesan seseorang dalam berusaha/berbisnis. Selain itu, memiliki banyak teman akan memperbanyak saudara dan berarti pula telah berusaha meningkatkan ketakwaan kepada Allah SWT. Pada saat yang sama hal ini juga bermakna seseorang telah melaksanakan perintah agama untuk senantiasa menyambungkan tali silaturrahim.

Silaturrahim merupakan sifat terpuji yang harus senantiasa dibiasakan karena memiliki banyak manfaat. Menurut alFaqih abu Laits Samarqandi seperti dikutip Rahmat Syafe'i (Syafe'i, 2003: 210) keuntungan bersilaturrahim ada sepuluh, yaitu:

1) Memperoleh ridha Allah SWT karena

Dia yang memerintahkannya.

2) Membuat gembira orang lain.

3) Menyebabkan pelakunya menjadi disukai malaikat.

4) Mendatangkan pujian kaum Muslimin padanya.

5) Membuat marah iblis.

6) Memanjangkan usia.

7) Menambah barakah rezekinya.
8) Membuat senang kaum kerabat yang telah meninggal, karena mereka senang jika anak cucunya selalu bersilaturrahim.

9) Memupuk rasa kasih sayang di antara keluarga/famili sehingga timbul semangat saling membantu ketika berhajat.

10) Menambah pahala sesudah pelakunya meninggal karena ia akan selalu dikenang dan didoakan karena kebaikannya.

Apalagi bila mereka menyadari bahwa mereka yang memutuskan silaturrahim, diancam tidak akan mendapatkan kebahagiaan kelak di akhirat, yaitu mereka tidak masuk surga.

\section{Pendidikan Egaliter (Persamaan Derajat)}

Pendidikan persamaan derajat ini terdapat dalam firman Allah yang artinya: Ketakwaan merupakan tolak ukur untuk membedakakan apakah derajat seseorang itu mulia atau tidak.

Tolok ukur yang digunakan manusia selama ini seperti melimpahnya materi dan kedudukan bukanlah tolak ukur yang sebenarnya. Dengan demikian, kedudukan manusia itu semuanya sama, kecuali taqwanya.

Salah satu sendi ajaran Islam yang paling agung adalah prinsip persamaan hak yang telah disyariatkan bagi umat manusia. Semua manusia sama dalam pandangan Islam tidak ada perbedaan antara yang hitam dan yang putih, antara kuning dan merah, kaya dan miskin, raja dan rakyat, pemimpin dan yang dipimpin. Oleh karenanya, tidaklah tepat kalau di antara manusia terjadi kesombongan disebabkan karena bedanya pangkat maupun keturunannya. Orang yang paling mulia di sisi Allah adalah yang paling 
bertaqwa (Ibrahim, 1989: XIII/514). Hal ini juga ditegaskan dalam salah satu Hadist yang berbunyi:

kepada seseorang yang tidak melapangkan tempat duduk di sisi Nabi SAW, hai fulan! Kemudian Nabi SAW bersabda: Sesungguhnya Engkau tidak ada kelebihan antara satu dengan lainnya kecuali dalam agama dan takwa. (HR Thabrani)

Dengan demikian Islam dalam ajaran syariatnya, mengukuhkan adanya penghormatan terhadap manusia, menjamin kebebasan kehidupan dan hak asasi mereka, dan kedudukan mereka di hadapan hukum adalah sama. Tidak ada ajaran untuk melebihkan satu dari yang lain di hadapan hukum, kecuali dengan mengamalkan kebaikan dan meninggalkan perbuatan dosa dan pelanggaran. Adapun bentuk dari pelaksanaan persamaan hak itu antara lain ialah penerapan hukum bagi pelaku kejahatan tanpa membeda-bedakan status sosial pelakunya.

JIka dicermati lebih jauh, salah satu penyebab kemunduran suatu bangsa adalah karena penegakkan hukum belum sepenuhnya dilaksanakan dengan baik, Misalnya, seseorang dinilai atau dipandang berdasarkan status sosialnya. Rasulallah SAW adalah pribadi yang paling tegas dalam menegakkan keadilan. Hal ini tercermin dari dari sebuah peristiwa ketika pada masa itu terjadi sebuah pencurian, beliau mengatakan seandainya yang mencuri itu adalah Fatimah maka akulah yang akan memotong tangannya. Oleh karena itu, jika suatu bangsa mengharapkan negara yang makmur, aman dan sejahtera maka salah satu cara yang perlu dilakukan adalah dengan menegakkan prinsip keadilan, dan menghukumnya bagi yang melanggar peraturan.

\section{Nilai Pendidikan Akhlak dalam Surat Luqman: 12-19}

Al Quran banyak menyebut tentang akhlak mulia dan menganjurkan agar manusia mengamalkannya. Anjuran Alquran kepada manusia untuk beramal salih adalah bukti bahwa Islam senantiasa menegakkan kebajikan dan kebaikan setiap orang. Amal salih merupakan manifestasi dari pengakuan seorang muslim akan kebenaran iman, ilmu, dan akhlak. Nilainilai pendidikan akhlak dan sikap hidup yang mulia terkandung dalam surah Lukman sebagai berikut:

\section{Syukur}

Dan sesungguhnya telah kami berikan hikmat kepada Luqman, yaitu: "Bersyukurlah kepada Allah. dan barangsiapa yang bersyukur (kepada Allah), maka sesungguhnya dia bersyukur untuk dirinya sendiri; dan barangsiapa yang tidak bersyukur, maka sesungguhnya Allah Mahakaya lagi Maha Terpuji." Dan kami perintahkan kepada manusia (berbuat baik) kepada dua orang ibu-bapaknya; ibunya telah mengandungnya dalam keadaan lemah yang bertambah-tambah, dan menyapihnya dalam dua tahun. Bersyukurlah kepadaku dan kepada ibu bapakmu, hanya kepada-Kulah kembalimu.

Pada kedua ayat tersebut Allah telah menunjukkan dua kali perintah bersyukur, kepada Allah dan kepada kedua orang tua.Syukur kepada Allah adalah manifestasi dari segala nikmat dan anugerah yang telah diberikan-Nya kepada Muslim.Syukur kepada Allah adalah mengingat nikmat-Nya sambil memuji kebesaran-Nya.Sedang kepada orangtua merupakan manifestasi dari segala 
perhatian dan curahan kasih sayang kepada orangtua yang telah mengasuh anaknya.Syukur merupakan bagian dari keimanan, karena syukur berarti menyadari bahwa tidak ada yang memberi nikmat kecuali Allah SWT.

Kata syukur dengan berbagai bentuk turunannya ditemukan sebanyak 75 kali dalam 67 ayat (Al-Baqi', 1992: 489-491). Menurut Wahbah Azzuhaili (1991: XXI/179), menunjukkan betapa pentingnya mensyukuri nikmat. Lebih lanjut dijelaskan andaikata manusia ingin menghitung dan mengidentifikasi nikmat Allah, niscaya ia tidak akan mampu. Sebab nikmat Allah itu sangat besar jumlahnya (tak terhitung) yang terus menerus ada, sedangkan akal manusia itu sangat terbatas dan lemah.

Nikmat adalah kesenangan, pemberian atau karunia yang diberikan-Nya kepada manusia. Menurut Imam Ghazali nikmat berarti setiap kebaikan yang dapat dirasakan kelezatannya dalam kesenangan hidup, tetapi nikmat yang sejati adalah kesenangan hidup di akhirat (I. Al-Ghazali, 1997: 88).

Sedangkan syukur menurut HAMKA (1991: 1/288) adalah orang yang mampu mempertinggi dirinya sendiri dengan cara mengenang dan menghargai jasa orang lain. Orang yang paling berjasa terhadap diri kita adalah kedua orang tua. Sehingga Tuhan pun memerintahkan setiap manusia agar bersyukur kepada keduanya, dan pada perinsipnya yang maha berjasa adalah Allah Swt. Dalam hal ini, Imam alQusyairi mengutib dari Syeh Ali Dahaq yang mengatakan bahwa hakikat syukur menurut para ahli ialah pengakuan terhadap nikmat yang diberikan-Nya yang dibuktikan dengan ketundukannya (K. Pemadi, 1995: 104).

Sebagai makhluk yang beradab sudah semestinya manusia senantiasa bersyukur
kepada-Nya, akan tetapi pertanyaannya kemudian adalah bagaimana cara bersyukur yang baik itu bisa terlaksana. Namun, sebelum hal itu dijelaskan perlu disampaikan terlebih dahulu perbedaan antara kata al-syukr (berterima kasih) dan kata al-hamd (memuji) agar tidak terjadi kesalahan persepsi dalam memahami kedua kata tersebut.Perbedaan kedua kata tersebut pada dasarnya terletak pada tingkat pelaksanaannya. Kata al-hamd itu terkadang hanya diucapkan dalam lisan saja tanpa adanya tindakan. Sementra itu, kata al-syukr biasanya sudah mencakup syukur secara lisan dan syukur dengan perbuatan (Said Agil, 2002: 309).

\section{Sabar}

Firman Allah SWT,

Bersabarlah terhadap apa yang menimpa kamu. Sesungguhnya yang demikian itu termasuk hal-hal yang diwajibkan (oleh Allah).

Ungkapan tersebut merupakan pesan ketiga Lukman kepada anaknya dalam rangkaian nasihat yang direkam dalam ayat 17 surah Lukman. Sabar dalam menahan kehendak nafsu demi mencapai sesuatu yang baik atau lebih baik (Shihab, 2002: 180). Secara umum kesabaran dapat dibagi dalam dua pokok: pertama, Sabar jasmani yaitu kesabaran dalam menerima dan melaksanakan perintah-perintah keagamaan yang melibatkan anggota tubuh, seperti sabar dalam melaksanakan ibadah haji yang melibatkan keletihan atau sabar dalam peperangan membela kebenaran. Termasuk pula dalam kategori ini, sabar dalam menerima cobaan-cobaan yang menimpa jasmani seperti penyakit, penganiayaan dan semacamnya.Kedua, adalah sabar rohani menyangkut kemampuan menahan kehendak nafsu yang dapat mengantar kepada kejelekan, 
seperti sabar menahan amarah, atau menahan nafsu lainnya (Shihab, 2002: 181).

Sebagai hamba Allah SWT, manusia tidak terlepas dari segala ujian yang menimpa padanya, baik musibah yang berhubungan dengan diri sendiri maupun musibah dan bencana yang menimpa pada sekelompok manusia maupun bangsa. Terhadap segala kesulitan dan kesempitan yang bertubi-tubi dan terus menerus maka hanya sabar yang memancarkan sinar yang memelihara seorang muslim dari kejatuhan dan kebinasaan. Memberikan hidayah yang menjaga diri dari putus asa, karena dalam al-Qur'an manusia menempati kedudukan istimewa dalam alam semesta ini (Langgulung, 1989: 57).

Manusia di dunia tidak lepas dari kemungkinan, mungkin suatu yang terjadi pada dirinya atau keluarganya, mungkin sesuai dengan keinginannya dan mungkin juga yang terjadi sesuatu yang tidak sesuai dengan keinginannya.Terhadap kemungkinan yang kedua inilah seseorang harus bersabar diri dalam menghadapi sehingga bisa memperoleh keberuntungan dalam hidupnya.Antara seseorang dengan yang lainnya dalam menghadapi cobaan hidup tentu berbeda-beda, ada yang dalam menghadapi cobaan yang menimpa pada diri dan keluarganya mereka senantiasa menyesal, putus asa dan tidak bersabar diri.Di samping itu ada pula dalam menghadapi cobaan dalam hidupnya mereka penuh dengan kesabaran dan tawakal kepada Allah SWT dengan hati yang ikhlas.

Kondisi mental sangat menentukan dalam kehidupan.Hanya orang yang sehat mentalnya yang dapat merasakan kebahagiaan, mampu dan sanggup menghadapi berbagai kesukaran serta berani menjawab tantangan hidup. Para ahli mengemukakan bahwa yang paling baik dan paling membawa kepada kebahagiaan adalah hanya keserasian (keharmonisan) antara pikiran, perasaan dan perbuatan (Daradjat, 1998: 13).

Oleh karenanya sabar merupakan media yang paling ampuh dalam mengobati berbagai penyakit kejiwaan, sabar merupakan proses pengosongan jiwa dan pemenuhan dengan sifat-sifat baik. Sabar merupakan proses pengosongan jiwa dari sifat-sifat permusuhan dan ketertarikan daripada kecenderungan-kecenderungan syahwat. Sabar jauh dari penyakit dan godaan jiwa, sehingga dengan demikian seseorang yang sabar akan memperoleh ketenangan jiwa yang diharapkan setiap insan (An-Najjar, 2001: 242). Sehingga dapat disimpulkan bahwa kebajikan dan kedudukan tertinggi diperoleh seseorang karena kesabarannya.

\section{Berbakti Kepada Kedua Orangtua}

Dan kami perintahkan kepada manusia (berbuat baik) kepada dua orang ibubapaknya; ibunya telah mengandungnya dalam keadaan lemah yang bertambahtambah, dan menyapihnya dalam dua tahun.Dan jika keduanya memaksamu untuk mempersekutukan dengan Aku sesuatu yang tidak ada pengetahuanmu tentang itu, maka janganlah kamu mengikuti keduanya, dan pergaulilah keduanya di dunia dengan baik.

Perintah berbakti kepada orangtua yang dimuat pada kedua ayat tersebut, dinilai oleh banyak ulama bukan bagian dari pengajaran Lukman kepada anaknya.Dia disisipkan dalam Alquran untuk menunjukkan betapa penghormatan dan kebaktian kepada orangtua menempati tempat kedua setelah pengagungan kepada Allah SWT. Perintah berbuat baik kepada kedua orangtua sering disertakan 
dengan perintah menyembah Allah SWT(Katsir, 2009: 3/1087). Hal ini dapat dilihat pula pada surah al-Isra' ayat 23 berbunyi, Dan Tuhanmu telah memerintahkan supaya kamu jangan menyembah selain dia dan hendaklah kamu berbuat baik pada ibu bapakmu dengan sebaik-baiknya.

Tetapi kendati nasihat ini bukan nasihat Lukman, tetapi tidak berarti bahwa beliau tidak menasihati anaknya dengan nasihat yang serupa. Ulama menilai ayat tersebut sebagai lanjutan dari nasihat Lukman menyatakan: Lukman menyampaikan itu kepada anaknya dengan wasiat itu seperti apa yang dinasihatkan menyangkut hak kami. Hanya saja kata ulama itu redaksinya diubah agar nasihat tersebut mencakup semua manusia bukan hanya putra Lukman itu (Shihab, 2002).

Pada ayat tersebut juga dinyatakan bahwa sebagai penghormatan dan bakti kepada kedua orangtua, meskipun kamu berbeda keyakinan hendaknya tetap menghormati dan bergaul dengan keduanya selama menyangkut urusan duniawi dan janganlah kamu mengikuti keyakinan atau agama mereka, yakni mempersekutukan Allah SWT meskipun mereka memaksamu.

\section{Menghindari Keangkuhan}

Dan janganlah kamu memalingkan mukamu dari manusia (karena sombong) dan janganlah kamu berjalan di muka bumi dengan angkuh.Sesungguhnya Allah tidak menyukai orang-orang yang sombong lagi membanggakan diri.Dan sederhanalah kamu dalam berjalandan lunakkanlah suaramu.Sesungguhnya seburuk-buruk suara dialah suara keledai.

Kedua ayat tersebut merupakan upaya menanamkan sikap hidup yang baik kepada anak mencakup penanaman budi pekerti luhur, sopan santun dan akhlak yang berbudi.Nasihat Lukman yang berkaitan dengan satu materi pengajaran akidah diselingi pengajaran akhlak, bukan bermaksud agar peserta didik tidak jenuh dengan satu materi, tetapi untuk mengisyaratkan bahwa ajaran akidah dan akhlak merupakan suatu kesatuan yang tidak dapat dipisahkan.

Nilai akhlak yang ditekankan dalam ayat tersebut ialah untuk tidak bersikap sombong, baik bersikap angkuh atau membanggakan diri.Karena kesombongan menjadikan manusia ingkar terhadap kebenaran yang datang dari-Nya, hingga Allah mengunci hati mereka. Kata sombong dalam Al-Qur'an dan berbagai bentuk variannya menurut perhitungan ulama disebutkan 66 kali (Baqi, 1987: 88).

Sombong atau angkuh merupakan pribadi buruk yang telah menjadi sifat yang melekat pada diri, menganggap lebih dari yang lain sehingga menutupi kekurangan serta selalu merasa lebih (lebih kaya, lebih pintar, lebih dihormati, lebih mulia dan lebih beruntung) dari orang lain. Orang seperti ini biasanya memandang orang lain lebih buruk, lebih rendah dan tidak mau mengakui kelebihan orang lain karena tindakan itu menurutnya sama dengan merendahkan dan menghinakan diri sendiri (Yunus, 1994: 4).

Larangan untuk bersikap sombong bukan tanpa alasan. Ibnu Katsir menyebutkan lima dampak negatif dari bersikap sombong, antara lain: jauh dari kebenaran, mati hati, binasa dan gagal, dibenci Allah, dan calon penghuni neraka (Katsir, 2009: 3/1448). Untuk terhindar dari perilaku sombong, ada lima cara yang bisa dilakukan. Pertama, meningkatkan keimanan kepada Allah ta'ala dengan memperbanyak berdzikir; kedua, meningkatkan ibadah baik yang bersifat 
wajib maupun sunnah; ketiga, ikhlas dalam perkataan dan perbuatan; keempat, selalu bersyukur atas karunia Allah; dan kelima, bersikap tawadhu (Hasiah, 2018: 195).

\section{Kesimpulan}

Akhlak merupakan cermin kepribadian seseorang, sehingga baik buruknya seseorang dapat dilihat dari kepribadiannya.Al-Qur'an adalah sumber pokok dalam berprilaku dan menjadi acuan kehidupan, karena di dalamnya memuat berbagai aturan kehidupandimulai dari hal yang urgent sampai kepada hal yang sederhana sekalipun. Jika al-Qurean telah melekat dalam kehidupan setiap insan, maka ketenangan dan ketentraman bathin akan mudah ditemukan dalam realita kehidupan.

Akhlak sangat diperlukan dalam kehidupan, terutama dalam era globalisasi ini. Suatu negara bahkan sampai kepada keluarga sebagai kelompok masyarakat terkecil tidak akan damai dan sejahtera bila tidak didukung dengan akhlak yang mulia. Surat Al-Hujurat: 11-13 secara gamblang menjelaskan nilai pendidikan akhlak sebagai modal dalam berinteraksi dengan masyarakat luas. Adapun surat Luqman 12-19 menanamkan nilai-nilai pendidikan akhlak yang bersifat pribadi dan individualis. MeskipunLuqman 12-19 lebih pada penataan akhlak pribadi seseorang namun ia juga menjadi "software" dalam penataan bersosial secara luas sehingga seseorang menjadi shalih secara individual maupun sosial.

\section{Daftar Pustaka}

Al-Baqi', M. F. 'Abd. (1992). al-Mu'jam al-Mufahras li Alfaz al-Qur'an alKarim. Dar al-Fikr.

Al-Ghazali, I. (1997). Mutiara Ihya' 'Ulumuddin,. Mirzan.

Al-Ghazali, M. (1999). Berdialog dengan al-Qur"an. Mizan.

Al-Khattan, M. K. (1996). Studi Ilmu-Ilmu Al-Qur"an. Pustaka Litera Antar Nusa.

Al-Maraghi, A. M. (1992). Terjemahan Tafsir Al-Maraghi. Toha Putra.

Aly, H. N. (1999). Ilmu Pendidikan Islam (I). Logos Wacana Ilmu.

Amini, I. (2006). Agar tak Salah Mendidik (I). Al-Huda.

An-Naisabury, A. al-H. M. al-H. (1996). Shahih Muslim. Darul Hadits.

An-Najjar, A. (2001). Ilmu Jiwa dalam Tasawuf. Pustaka Azzam.

An-Nawawi, M. A. Z. Y. bin S. (2000). AlAdzkar An-Nawawiyah. Darul Fikr.

Asy-Syafi'i, A.-I. (1993). Al-Adzkar (III). Dar al-Mishriyah.

Aziz, S. bin A. (1999). Jamiut Tirmidzi. Darussalam.

Azzuhaili, W. (1991). Tafsir Al-Munir. Darul Fikri.

Baqi, M. F. A. (1987). Al-Mu'jam alMufahras lil Al-alfaz Alquran. Dar alFikr.

Baraja, U. B. A. (1999). Akhlak lil Banin. Ahmad Nabhan.

Daradjat, Z. (1995). Pendidikan Islam dalam Keluarga dan Sekolah. Ruhama.

Daradjat, Z. (1998). Kesehatan Jiwa dalam Islam. PT. Pertja.

Darajat, Z. (1991). Ilmu Jiwa Agama. Bulan Bintang.

Hadi, S. (2000). Metodologi Research. 
Andi Offset.

Hamka. (1991). Tafsir Al-Azhar. Pustaka Panjimas.

Hasiah. (2018). Mengintip Prilaku Sombong dalam Al-Qur'an. ElQanuny, 4(2).

Ibrahim, A. bin I., \& Sayyid, A. (1989). AlMuharrar Al-Wajiz. Dar al-Mishriyah.

Ishak, M. N. dan A. (1993). Moral dan Kognisi Islam. Alfabeta.

Katsir, A. al-F. al-H. I. (2009). Tafsir alQur'an al- 'Azhim. Dar al-Fikr.

Langgulung, H. (1989). Manusia dan Pendidikan suatu Analisa Psikologi Filsafat dan Pendidikan. Pustaka Al Husna.

Langgulung, H. (1991). Manusia dan Pendidikan Suatu Analisa Psikologi dan Pendidikan. PT. Al-Husna Zikra.

Margono, S. (1997). Metodologi Penelitian Pendidikan. PT. Rineka Cipta.

Marzuki. (2002). Metodologi Riset. Prasetya Widi Pratama.

Mustafa, A. (1999). Akhlak Tasawuf (III). Pustaka Setia.

Nata, A. (2005). Pendidikan Dalam Persfektif Hadits (I). UIN Jakarta Press.

Qardawi, Y. (2004). Halal Haram dalam Islam, (I). Akbar.

Qutbh, S. (2004). Tafsir Fi Zhilalil Qurían. Gema Insani Press.

Ramayulis. (2002). Ilmu Pendidikan Islam (III). Kalam Mulia.

Rifai, M. N. (2000). , Kemudahan dari Allah Ringkasan Tafsir Ibnu Katsir, . Gema Insani Press.

Salminawati. (2016). Filsafat Pendidikan Islam: Membangun Konsep Pendidikan Yang Islami,. Citapustaka Media Printis.

Shihab, M. Q. (2002). Tafsir al-Misbah Pesan, Kesan dan Keserasian alQur'an. Lentera Hati.

Syafe'i, R. (2003). Aqidah, akhlak, Sosial dan Hukum (II). Pustaka Setia.

Syah, M. (2004). Psikologi Pendidikan dengan Pendekatan Baru (IX). Rosda Karya.

Thabrani, A. M. (2006). MAHKOTA SASTRA IMAM SYAFI'I. OKARA, II(I).

Warsito, H. (1995). Pengantar Metodologi Penelitian. Gramedia Pustaka Utama.

Yunus, M. (1994). Pendidikan agama Islam. Erlangga. 